\title{
INTRODUCTION AND EVALUATION OF IMPROVED BANANACULTIVARS FOR AGRONOMIC AND YIELD CHARACTERISTICS IN KENYA
}

\author{
J. NJUGUNA, F. NGUTHI, S. WEPUKHULU, F. WAMBUGU, D. GITAU, M. KARUOYA \\ and D. KARAMURA ${ }^{1}$ \\ Kenya Agricultural Research Institute, National Horticultural Research Centre, \\ P.O. Box 220, 01000,Thika Kenya \\ ${ }^{1}$ Bioversity International, P.O. Box 24384, Kampala, Uganda
}

\begin{abstract}
Banana (Musa spp.) is one of the most important food and cash crops in Kenya. However, most of the cultivars grown particulary the local ones are low yielders and are thus not very suitable for commercial production. To address this constraint, a study was conducted at Kenya Agricultural Research Institute, Thika to evaluate introduced improved cultivars for agronomic and yield characteristics. The study involved six FHIA and four Cavendish type of bananas obtained from Bioversity International. Different growth and yield parameters were collected for the first, second and third crop cycles. Cultivar SH3436-9 took the longest time to reach the shooting stage, while SH3640 took the shortest time. FHIA 25 took the longest time from shooting stage to maturity, while FHIA 23 took the shortest time. FHIA 25 had the highest bunch weight in the first and third crop cycles, while FHIA 17 had the highest weight in the second crop cycle. Overall, GCTCV-119 produced the smallest bunch. For finger length, FHIA 21 and FHIA 25 led in the first and second crop cycle, respectively. Cultivars FHIA 17, FHIA 18 and FHIA 25 were identified as the most promising for commercial production, but further evaluation is required in other zones to establish whether this impressive performances would be sustained.
\end{abstract}

Key Words: Bunch weight, FHIA banana, Musa spp.

\section{RÉSUMÉ}

La banane (Musa spp). Est l'une des nourriture les plus importantes et de production des revenus au Kenya. Cependant, la plupart des cultivars dévéloppées particulièrement local est moins productitif et est moins convenable pour la production commerciale. Pour adresser cette contrainte, une étude a été dirigée à Institut de Recherche Agricole au Kenya, Thika pour évaluer des cultivars améliorés introduits pour les caractéristiques agronomique et de rendement. L'étude a impliqué six FHIA et quatre types de bananes Cavendish obtenues d'INIBAP. Les différentes croissances et nivequx de rendement ont été recueillis pour les premiers deuxièmes et troisièmes cycles de récolte. Le cultivar SH3436-9 a pris le temps le plus long pour atteindre l'étape de l'emergence de rejetons, pendant que SH3640 a pris le temps le plus court. FHIA 25 ont pris le temps le plus long concernant l'emergence de rejetons d'étape à l'échéance, pendant que FHIA 23 a pris le temps le plus court. FHIA 25 a eu le regime de plus haut poids dans le premier et troisième cycle de récolte, pendant que FHIA 17 a eu le poids le plus haut dans le deuxième cycle de récolte. En général, GCTCV-119 a produit le plus petit regime. Pour la longueur de doigts des bananes, FHIA 21 et FHIA 25 ont respectivement mené dans le premier et deuxième cycle de récolte. Les cultivars FHIA 17, FHIA 18 et FHIA 25 ont été identifiés comme le plus promettant pour la production commerciale, mais l'évaluation plus poussée est recmmandée dans les autres zones pour établir si ces performances impressionnantes seraient soutenues.

Mots Clés: Le poids de paquet, la banane de FHIA, Musa spp. 


\section{INTRODUCTION}

In Kenya, banana is a major fruit crop for both subsistence and commercial use. In priority setting exercise for Horticultural Crops Research (1996), banana was ranked the most important crop among the fruit crops. It is estimated to cover 74,000 hectares (about $2 \%$ of total arable land), (MOALD, 1997) ranging from 0 to $1800 \mathrm{~m}$ above sea level. Over a million tonnes are produced per year (MOALD, 1997). Nyanza and Western Provinces account for $64.4 \%$ of production, while Central and Eastern Provinces account for $26 \%$. The rest of the provinces are minor producers, with Rift Valley province accounting for $3.9 \%$ and Coast Province for 5.5\% (MOALD, 1997).

The crop is predominantly grown by smallscale farmers who have an average holding of 0.3 hectares making up to $13 \%$ of the total farm area (Qaim, 1999). Dijsksra and Migori (1994) reported that banana accounted for over $70 \%$ of farmer's incomes in Kisii. Recently, banana has become an important cash crop for semi-intensive medium scale farmers, who supply the urban markets in the country. This is more so where the income from traditional cash crops, especially coffee (Coffea arabica) frequently fluctuates and/or has drastically reduced. Continuous availability of harvestable bunch from a banana stool is especially important for farmers because it contributes to the year round security of food and income. The commonly grown varieties are the East Africa Highland bananas (Musa AAA) and Apple bananas (Musa AB/AAB) in Western and Nyanza Provinces, and Cavendish and Kampala (Musa AAA) in Central and Eastern Provinces (Nguthi et al., 1999)

Banana farmers are facing several challenges including low yields and diseases particularly Fusarium wilt (Panama) caused by Fusarium oxysporum fsp cubense (Kung'u 1995). Indeed, pests alone cause between $30-80 \%$ of banana losses depending on the variety (Speijer and Fogain, 1999). To address these challenges, there is a continuous need to introduce improved cultivars and evaluate them in different AgroEcological Zones (AEZ). In Kenya, a tetraploid FHIA 1 (Gold finger) has been evaluated and found to be high yielding, tolerant to Fusarium wilt disease, nematodes and drought. It has subsequently been adopted for commercial production as a dual-purpose cultivar for dessert and green-cooking use. The objective of this study was to identify high yielding cultivars for commercial production in Kenya.

\section{MATERIALS AND METHODS}

Tissue-cultured banana plantlets of nine cultivars sourced from International Network for the Improvement of Banana and Plantain (Bioversity International) through South Africa, and one local check were evaluated in a trial carried out at National Horticultural Research Centre, (NHRC), at Thika, from year 2001 to year 2004.

The Centre lies about $1500 \mathrm{~m}$ a.s.l, at $0^{\circ}$ and $37^{\circ} 41^{1}$ East and receives an average annual rainfall of $900 \mathrm{~mm}$. The trial was laid out in a randomised complete block design (RCBD), replicated three times. The cultivars used were, FHIA 02, FHIA 17, FHIA 18, FHIA 21, FHIA 23, FHIA 25, SH3640, SH 3436-9, GCTCV-119 and Cavendish Williams (local check). Planting was done in holes measuring $60 \mathrm{~cm} \mathrm{X} 60 \mathrm{~cm}$ and spaced at $3 \mathrm{~m} \mathrm{X} 2 \mathrm{~m}$ between and within the rows, respectively, by first mixing the topsoil with $200 \mathrm{~g}$ of Di-ammonium phosphate (DAP), $20 \mathrm{~kg}$ of compost manure and $60 \mathrm{~g}$ of Furadan $5 \mathrm{G}$ (Carbufuran) for the control of nematodes and other soil borne insects. Top dressing was done with Calcium Ammonium Nitrate (CAN) at a rate of 200 g plant $^{-1}$ per year. Weeding was done when necessary.

Data collected were: plant height and girth at shooting, number of functional and total leaves at shooting and number of days to shooting and maturity. Functional leaves were considered to be those ones with more than $50 \%$ of their surface area still green. Plant height and girth were measured using a measuring tape, while total leaves were determined by counting all the existing leaves per plant.

At harvest the data collected included bunch weight and the length and width of the longest finger of the third hand. The ratio of finger length to finger width was also determined. The bunches were considered mature when fingers of the second hand attained round shape (Nguthi et.al., 1999). Bunch weight was determined by using a spring balance, while the finger length and width were measured using a measuring tape. This was 
done for the first, second and third crop cycles. Girth width was measured at the thickest point. Bunch weight, finger length and finger width are important parameters in banana marketing thus the reason they were considered in this study. The data were analysed using Statistics Analysis System (SAS) for analysis of variance (ANOVA) and means were separated by the StudentNewman-Keuls test.

\section{RESULTS}

The differences in growth parameters of the 10 evaluated cultivars are given in Table 1 . Time taken by different cultivars from planting to shooting varied with cultivar SH 3436-9 taking the longest (648.7 days), while SH3640 taking the shortest (314.5 days). For plant height at shooting, FHIA 21, FHIA 23, FHIA 25 and GCTCV-119 were significantly taller than the other cultivars. Besides having the highest mean height at flowering, FHIA 25 also had significantly bigger girth at shooting than all other cultivars. Total leaves at shooting ranged from 9.6 for FHIA 21 to 12.7 for Cavendish Williams. Cultivar SH 3436-9 took almost twice the time taken by FHIA 23 from planting to maturity while for days from shooting to harvest maturity, there was a difference of 53 days between the cultivar that took the shortest time (GCTCV-119) and the one that took the longest time ( FHIA 25) (Table 1).

The differences in finger length, width of the third hand and ratio of finger length to width of evaluated cultivars are given in Tables 2 and 3, while the bunch weights for the three crop cycles are given in Table 4. For the finger length of the third hand, FHIA 21 had significantly $(p<0.01)$ longer fingers than the rest of the cultivars. Cultivar FHIA 25 had the second longest fingers after FHIA 21, while FHIA 23 had the shortest fingers (mean $17.6 \mathrm{~cm}$ ). Cultivar SH3640 had the thickest fingers in both cycle 1 and 2 . The ratio of finger length to finger width followed the same trend such that the cultivars with longer fingers like FHIA 17 and FHIA 25 also had bigger ratio than cultivars with shorter fingers like FHIA 23 in both cycles. Bunch weight varied widely depending on cultivar. Cultivar FHIA 25, for example, produced bunches which were almost three times heavier than cultivar GCTCV-119 and about 1.5 times heavier than bunches of cultivar Cavendish Williams (control) in the first cycle. The trend persisted in the other two cycles considered. However, for cultivar GCTCV-119,

TABLE 1. Days to shooting, plant height, girth measurement, functional leaves and total leaves at shooting, days from shooting to harvest and total days from planting to harvest maturity in the first cycle*

\begin{tabular}{llllllll}
\hline Cultivar & ${ }^{*}$ D.S & ${ }^{*} \mathrm{H} . \mathrm{S}(\mathrm{cm})$ & ${ }^{*} \mathrm{G} . \mathrm{S}(\mathrm{cm})$ & ${ }^{*} \mathrm{~F} . \mathrm{L} . \mathrm{S}$ & ${ }^{*}$ T.L.S & ${ }^{*}$ D.S.M & ${ }^{*}$ T.P.M \\
\hline FHIA02 & $355.8 \mathrm{def}$ & $218.2 \mathrm{c}$ & $56.5 \mathrm{c}$ & $10.3 \mathrm{bcd}$ & $10.9 \mathrm{bcd}$ & $195.7 \mathrm{a}$ & $505.4 \mathrm{e}$ \\
FHIA 17 & $401.6 \mathrm{c}$ & $270.5 \mathrm{ab}$ & $70.7 \mathrm{~b}$ & $10.1 \mathrm{bcd}$ & $10.4 \mathrm{~cd}$ & $172.9 \mathrm{~b}$ & $564.9 \mathrm{dc}$ \\
FHIA18 & $376.6 \mathrm{cde}$ & $251.8 \mathrm{~b}$ & $67.4 \mathrm{~b}$ & $10.0 \mathrm{bcd}$ & $10.6 \mathrm{bcd}$ & $177.8 \mathrm{~b}$ & $502.1 \mathrm{de}$ \\
FHIA21 & $388.9 \mathrm{~cd}$ & $280.2 \mathrm{a}$ & $66.4 \mathrm{~b}$ & $8.8 \mathrm{~d}$ & $9.6 \mathrm{~d}$ & $178.9 \mathrm{~b}$ & $529.0 \mathrm{dce}$ \\
FHIA23 & $333.8 \mathrm{ef}$ & $287.8 \mathrm{a}$ & 69.7 & $10.9 \mathrm{bc}$ & $11.9 \mathrm{ab}$ & $148.8 \mathrm{c}$ & $482.7 \mathrm{e}$ \\
FHIA25 & $416.7 \mathrm{c}$ & $289.6 \mathrm{a}$ & $76.6 \mathrm{a}$ & $10.9 \mathrm{bc}$ & $11.7 \mathrm{abc}$ & $201.3 \mathrm{a}$ & $595.3 \mathrm{c}$ \\
SH3640 & $314.5 \mathrm{f}$ & $253.0 \mathrm{~b}$ & $59.2 \mathrm{c}$ & $11.4 \mathrm{ab}$ & $11.8 \mathrm{abc}$ & $180.1 \mathrm{~b}$ & $494.6 \mathrm{de}$ \\
SH3436-9 & $648.7 \mathrm{a}$ & $249.9 \mathrm{~b}$ & $55.7 \mathrm{c}$ & $9.6 \mathrm{~cd}$ & $10.1 \mathrm{~d}$ & $171.6 \mathrm{~b}$ & $820.3 \mathrm{a}$ \\
GCTCV-119 & $530.2 \mathrm{~b}$ & $279.9 \mathrm{a}$ & $43.0 \mathrm{~d}$ & $9.7 \mathrm{~cd}$ & $10.3 \mathrm{~cd}$ & $148.8 \mathrm{c}$ & $679.1 \mathrm{~b}$ \\
Cavendish Williams & $351.1 \mathrm{def}$ & $161.2 \mathrm{~d}$ & $57.9 \mathrm{c}$ & $12.4 \mathrm{a}$ & $12.7 \mathrm{a}$ & $188.2 \mathrm{a}$ & $539.3 \mathrm{dce}$ \\
& & & & & & & \\
P-value & $<0.01$ & $<0.01$ & $<0.01$ & $<0.01$ & $<0.01$ & $<0.01$ & 0.01 \\
CV (\%) & 11.82 & 9.15 & 11.12 & 14.7 & 13.97 & 9.81 & 13.10 \\
\hline
\end{tabular}

Means with the same letter along the column are not significantly different, SNK test at $P<0.05$

*Bunch maturity=When fingers attained round shape; *D.S= days to shooting; ${ }^{*}$ H.S=Height at shooting; ${ }^{*}$.S. $=$ Girth at shooting; ${ }^{*}$ F.L.S=Functional leaves at shooting; ${ }^{*}$ T.L.S=Total leaves at shooting; *D.S.M= Days from shooting to maturity ${ }^{*}$ T.P.M=Time from planting to maturity 
TABLE 2. Bunch finger length and width of third hand and finger length to finger width ratio in the first cycle

\begin{tabular}{lccc}
\hline Cultivar & Finger length $(\mathrm{cm})$ & Finger width $(\mathrm{cm})$ & Finger length/finger width ratio \\
\hline FHIA02 & $18.3 \mathrm{ef}$ & $12.0 \mathrm{~d}$ & $1.485 \mathrm{dc}$ \\
FHIA 17 & $21.1 \mathrm{~cd}$ & $12.1 \mathrm{dc}$ & $1.746 \mathrm{ab}$ \\
FHIA18 & $20.4 \mathrm{~cd}$ & $11.8 \mathrm{~d}$ & $1.755 \mathrm{ab}$ \\
FHIA21 & $24.7 \mathrm{a}$ & $12.4 \mathrm{dc}$ & $1.959 \mathrm{a}$ \\
FHIA23 & $17.6 \mathrm{f}$ & $13.4 \mathrm{ba}$ & $1.314 \mathrm{~d}$ \\
FHIA25 & $23.2 \mathrm{~b}$ & $13.0 \mathrm{bc}$ & $1.794 \mathrm{ba}$ \\
SH3640 & $19.6 \mathrm{de}$ & $13.9 \mathrm{a}$ & $1.522 \mathrm{dc}$ \\
SH3436-9 & $22.1 \mathrm{bc}$ & $12.4 \mathrm{dc}$ & $1.789 \mathrm{ab}$ \\
GCTCV-119 & $21.3 \mathrm{~cd}$ & $12.5 \mathrm{dc}$ & $1.699 \mathrm{bc}$ \\
Cavendish Williams & $18.3 \mathrm{ef}$ & $12.4 \mathrm{dc}$ & $1.477 \mathrm{dc}$ \\
& & & \\
P-value & $<0.01$ & $<0.01$ & $<0.01$ \\
CV (\%) & 10.29 & 7.40 & 15.19 \\
\hline
\end{tabular}

Means with the same letter along the column are not significantly different, SNK test at $\mathrm{P}<0.05$

TABLE 3. Finger length and width of the $3^{\text {rd }}$ hand and finger length to finger width ratio during the second cycle

\begin{tabular}{lccc}
\hline Cultivar & $\begin{array}{c}\text { Finger length } \\
(\mathrm{cm})\end{array}$ & $\begin{array}{c}\text { Finger width } \\
(\mathrm{cm})\end{array}$ & $\begin{array}{c}\text { Finger length/finger width } \\
(\mathrm{cm})\end{array}$ \\
\hline FHIA02 & $17.6 \mathrm{f}$ & $12.1 \mathrm{e}$ & $1.541 \mathrm{a}$ \\
FHIA 17 & $24.1 \mathrm{abc}$ & $12.8 \mathrm{~cd}$ & $1.891 \mathrm{ab}$ \\
FHIA18 & $23.8 \mathrm{bc}$ & $12.7 \mathrm{cde}$ & $1.880 \mathrm{ab}$ \\
FHIA21 & $24.7 \mathrm{ab}$ & $12.3 \mathrm{de}$ & $2.00 \mathrm{ab}$ \\
FHIA23 & $19.9 \mathrm{e}$ & $14.1 \mathrm{a}$ & $1.419 \mathrm{~b}$ \\
FHIA25 & $25.6 \mathrm{a}$ & $13.0 \mathrm{~cd}$ & $2.581 \mathrm{a}$ \\
SH3640 & $21.6 \mathrm{~d}$ & $13.3 \mathrm{~b}$ & $1.623 \mathrm{~b}$ \\
SH3436-9 & $22.6 \mathrm{~cd}$ & $12.7 \mathrm{cde}$ & $1.788 \mathrm{ab}$ \\
GCTCV-119 & $22.8 \mathrm{~cd}$ & $12.7 \mathrm{cde}$ & $1.802 \mathrm{ab}$ \\
Cavendish Williams & $19.7 \mathrm{e}$ & $12.1 \mathrm{de}$ & $1.618 \mathrm{~b}$ \\
& & & \\
P-value & $<0.01$ & $<0.01$ & $<0.01$ \\
CV (\%) & 8.21 & 4.77 & 47.40 \\
\hline
\end{tabular}

Means with the same letter along the column are not significantly different, SNK test at $P<0.05$

there was consistent increase in bunch weight from cycle 1 to cycle 3 .

\section{DISCUSSION}

There were considerable variations between the cultivars in terms of time taken before flowering, time taken from flowering to bunch maturity and total time from planting to bunch maturity (Table 1). This can be explained by the innate genetic variability of these cultivars. Banana cultivars can generally be categorised as early, medium and late maturing ones. It is, however, interesting to note that cultivars which took shorter time to shooting, were also early in attaining maturity. Cultivars FHIA 23 and SH3640, for example, were the first ones to shoot and were also among the first ones to mature. Early maturity is a desirable characteristic because such cultivars are more likely to give higher yields over time. 
TABLE 4. Bunch weight in the first, second and third crop cycles

\begin{tabular}{lccc}
\hline Cultivar & $\begin{array}{c}\text { Mean bunch weight }(\mathrm{kg}) \\
\text { in the first cycle }\end{array}$ & $\begin{array}{l}\text { Mean bunch weight }(\mathrm{kg}) \\
\text { in the second cycle }\end{array}$ & $\begin{array}{c}\text { Bunch weight }(\mathrm{kg}) \\
\text { in the third cycle }\end{array}$ \\
\hline FHIA02 & $17.1 \mathrm{e}$ & $20.7 \mathrm{e}$ & $21.4 \mathrm{f}$ \\
FHIA 17 & $37.8 \mathrm{~b}$ & $39.5 \mathrm{a}$ & $30.8 \mathrm{~cd}$ \\
FHIA18 & $32.6 \mathrm{c}$ & $37 . \mathrm{a}$ & $34.6 \mathrm{~b}$ \\
FHIA21 & $25.5 \mathrm{~d}$ & $25.5 \mathrm{~d}$ & $19.2 \mathrm{f}$ \\
FHIA23 & $24.8 \mathrm{~d}$ & $31.2 \mathrm{~b}$ & $27.8 \mathrm{de}$ \\
FHIA25 & $41.4 \mathrm{a}$ & $38.6 \mathrm{a}$ & $39.2 \mathrm{a}$ \\
SH3640 & $30.0 \mathrm{c}$ & $31.1 \mathrm{~b}$ & $33.4 \mathrm{bc}$ \\
SH3436-9 & $30.4 \mathrm{c}$ & $27.3 \mathrm{dc}$ & $27.7 \mathrm{ed}$ \\
GCTCV-119 & $14.2 \mathrm{e}$ & $18.8 \mathrm{e}$ & $25.3 \mathrm{e}$ \\
Cavendish Williams & $25.8 \mathrm{~d}$ & $28.5 \mathrm{c}$ & $28.2 \mathrm{ed}$ \\
& & & \\
P-value & $<0.01$ & $<0.01$ & $<0.01$ \\
CV (\%) & 18.44 & 10.57 & 11.35 \\
\hline
\end{tabular}

Concerning the height and the number of functional and total leaves at flowering, cultivar Cavendish Williams was the shortest but had highest number of both functional and total leaves at shooting, while FHIA 25 was the tallest but was third in terms of number of leaves at shooting. This means that taller cultivar do not necessary have more leaves than shorter ones. In addition, this study established that yield may not only depend on the plant height and the number of functional or total leaves at flowering; other factors (yet to be discovered) may be involved. Similar results had been reported by Nguthi (2001). FHIA 25, for example, had the highest yield yet it had fewer leaves than Cavendish Williams, which had the lowest yield. This implies that genotype could be a more critical factor in determining the yield potential of a given cultivar. Short cultivars are preferred in areas that experience strong winds because they are less prone to toppling than tall ones. It was also established that, the cultivars with longer finger also had slender ones and, subsequently, had higher length to width ratio. This is an important attribute because the market preference for dessert bananas is mainly for long and slender fingers (Mbogoh, 2002).

The cultivars which were most promising in terms of bunch weight (FHIA 17,FHIA 18, FHIA 23 and SH 3640) have been reported to have had similar impressive results in other countries like
Sri lanka; while those which performed poorly like GCTCV-119 had shown similar poor performances in other countries (Risbab, 2004). In Sri lanka, for example, cultivars GCTCV-119 did not survive under field conditions. Similarly, in Kenya, it produced the lowest yield. This indicates that although ecological factors could have influenced their performances in Kenya, the type of genotype could be the more important influencing factor. Besides having higher yield potential, some of the promising cultivars, FHIA 17 and FHIA 23, have been reported to have resistance to Fusarium wilt (race 1 ), while SH 3640 and FHIA 18 are said to be tolerant to black Sigatoka (Gisella, 1998). Resistance/tolerance to these two diseases is a very important attribute because they (diseases) are of great economic importance to banana production in Kenya. In an evaluation trial carried out in Uganda to compare the FHIA cultivars and East Africa Highland banana landraces, it was found that FHIA 23 and FHIA 17 significantly out yielded the East Africa bananas (Nowakunda et.al. 1996). The two cultivars were also found to be resistant to Sigatoka and Fusarium wilt diseases and tolerant to weevils. In Kagera, Tanzania similar results were obtained (INIBAP, 2000)

Bunches from second cycle were generally heavier than those from first cycle. However, there was no much difference between second cycle and third cycle crop in terms of bunch 
weight. The better performance of second and third cycle crop, compared with the first one, can be attributed to better plant establishment at the latter two cycles than in the first one. This is consistent with findings of Nguthi (2001). Cultivars which had bigger bunches generally had longer fingers than those with smaller ones. Market normally prefers cultivars with long fingers.

\section{CONCLUSION}

The most promising banana cultivars in terms of yield potential are FHIA 17, FHIA 18 and FHIA 25, while GCTCV is the least promising. Further trials should, however, be carried out in other Agro-ecological zones to determine whether the results obtained at NHRC-Thika would be sustained. The three promising cultivars should be subjected to further tests like disease, pest and drought tolerance and consumer acceptability.

\section{ACKNOWLEDGEMENT}

The authors are grateful to Bioversity International for providing the evaluated cultivars. Thanks also go to the Centre Director, NHRC-Thika, Dr. Waturu, for funding this study.

\section{REFERENCES}

Dijsksra, T. and Magori, T.D. 1994. Horticultural Production and Marketing in Kenya, Part 4: Kisii and Nyamira District. Food and Nutrition Studies Programmee, Report No 52. Ministry of Planning and National Development, Nairobi, African Studies Centre, Leiden.
Gisella, O. 1998. IMTP Data Base. INIBAP INIBAP, 2000. INIBAP annual report.

Kung'u, J.N. 1995. Fusarium wilt and other banana diseases in Kenya. Infomusa 4 (2): 14-16.

Mbogoh, S.G. 2002. Baseline Socio-Economic Impact Study of the Tissue Culture. Banana Project in Kenya: A Basic Report.

MOALD. 1997. Provincial Annual Report. Ministry of Agriculture and Livestock Development. Horticultural Division.

Nguthi, F., Onyango, M., Muniu, F., Muthamia, J. and Njuguna, M. 1999. Biotechnology to Benefit Small-Scale Banana Producers in Kenya. Annual report, KARI. Nairobi, Kenya. Nguthi, F. 2001. Tissue culture techniques and their application in Agriculture: Case StudyBanana.

Nowakunda, K., Rubaihayo, P.R., Ameny, M.A. and Tushemereirwe, W. 1996. Consumer acceptability of introduced bananas in Uganda. Infomusa vol 8, No 2.Priority Setting for Horticultural Crops (1996). Research priorities of the KARI horticultural programmee.

Qaim, M. 1999. Assessing the Impact of Banana Biotechnology in Kenya. ISAAA Briefs No. 10.

Risbab Bulletin, 2004. NRMDP: An efficient tool for conservation, multiplication and distribution of improved varieties and popular local cultivars. INIBAP Newsletter for Asia and Pacific Network.

Speijer, P.R. and Fogain, R. 1999. Musa and Ensete nematodes pest status in selected African countries in. Proceedings of a workshop on banana IPM held in Nelspruit South Africa23-28 November 1998. INIBAP, Montpellier, France. 